\title{
Open educational resources: Conversations in cyberspace - Edited by Susan D'Antoni \& Catriona Savage
}

Citation for published version (APA):

Klemke, R., Kalz, M., Ternier, S., \& Specht, M. M. (2010). Open educational resources: Conversations in cyberspace - Edited by Susan D'Antoni \& Catriona Savage. British Journal of Educational Technology, 41(6), 968-970. https://doi.org/10.1111/j.1467-8535.2010.01135_1_1.x

DOI:

10.1111/j.1467-8535.2010.01135_1_1.x

Document status and date:

Published: 13/10/2010

Document Version:

Peer reviewed version

Document license:

CC BY-NC-ND

Please check the document version of this publication:

- A submitted manuscript is the version of the article upon submission and before peer-review. There can be important differences between the submitted version and the official published version of record. People interested in the research are advised to contact the author for the final version of the publication, or visit the DOI to the publisher's website.

- The final author version and the galley proof are versions of the publication after peer review.

- The final published version features the final layout of the paper including the volume, issue and page numbers.

Link to publication

\section{General rights}

Copyright and moral rights for the publications made accessible in the public portal are retained by the authors and/or other copyright owners and it is a condition of accessing publications that users recognise and abide by the legal requirements associated with these rights.

- Users may download and print one copy of any publication from the public portal for the purpose of private study or research.

- You may not further distribute the material or use it for any profit-making activity or commercial gain

- You may freely distribute the URL identifying the publication in the public portal.

If the publication is distributed under the terms of Article 25fa of the Dutch Copyright Act, indicated by the "Taverne" license above, please follow below link for the End User Agreement:

https://www.ou.nl/taverne-agreement

Take down policy

If you believe that this document breaches copyright please contact us at:

pure-support@ou.nl

providing details and we will investigate your claim.

Downloaded from https://research.ou.nl/ on date: 26 Apr. 2023 
PREPRINT Klemke, R., Kalz, M., Specht, M., Ternier, S. (2010). Open educational resources: Conversations in cyberspace - Edited by Susan D'Antoni \& Catriona Savage. British Journal of Educational Technology

"title": Book review for Learning Objects special issue "bibliodata": D'Antoni, Susan \& Savage, Catriona eds (2009) Open Educational Resources: Conversations in Cyberspace UNESCO Publishing ISBN 978-92-3104085-6 172 pp. \$0.00 (PDF) \$12.00 (Print)

"w-address": http://oerwiki.iiepunesco.org/index.php?title=Open Educational Resources: Conversations in C yberspace

"statement": the book adresses researches and practitioners in the open educational resources field and gives a broad overview over past and present approaches, lessons learned and issues to be addressed.

"value": 4

The book reports on a series of online forums organised by the UNESCO International Institute for Educational Planning (IIEP) about Open Educational Resources (OER) in 2005 and 2007 where more than 600 participants from 90 countries report about OER history, achievements, issues and challenges from OER provider and user perspectives. The selection of approaches from developed and developing countries represents a broad range of perspectives and approaches.

The book comprises four sections. Section 1 discusses lessons learned and challenges identified. Section 2 addresses research and development issues. Section 3 discusses motivational aspects and incentives. Section 4 addresses prioritized issues.

Section 1 introduces and defines the term OER ("The open provision of educational resources, enabled by information and communication technologies, for consultation, use and adaptation by a community of users for non-commercial purposes."). OER comprises resources for learners, for teachers and for quality assurance. As many OER initiatives are existing today, problems of retrievability replace problems of availability. Presented OER provider initiatives comprise:

- approaches towards free and open teaching \& learning resources,

- a web-based teaching and learning environment for interconnected, explorable and reusable content for communities,

- developing OER courses according to research results in cognitive and learning sciences,

- adding social support and providing an open source platform.

Complementary OER user initiatives comprise

- mirroring of OER in local infrastructures,

- translations of OER to other languages,

- and localisations of OER to other cultures including adaptations. 
PREPRINT Klemke, R., Kalz, M., Specht, M., Ternier, S. (2010). Open educational resources: Conversations in cyberspace - Edited by Susan D'Antoni \& Catriona Savage. British Journal of Educational Technology

Discussion points and challenges raised during the forum differ for providers and users. Provider's challenges include: suitable technologies, impact of OER, internal and external barriers, cross organisational standards, involvement effort, appropriate use of OER, authorship, attribution and incentives. Major issues of OER remain sustainability and intellectual property rights.

OER users request a shift towards collaborative approaches. Trade-offs include the need for technologically innovative courses opposed to the need for accessibility and stability. Language issues and cultural differences require open formats and adaptable content objects. Learning object repositories with standard metadata improve retrievability and accessibility.

Generally, OER is seen to have the potential of improving knowledge distribution world wide, when the issues mentioned are addressed. Communities of interest need to be formed to carry on the work in this direction. Furthermore, promotional activities to spread OER initiatives and usage are needed.

Section 2 focuses on research and development issues for OER. The need for an alignment of the OER movement with other initiatives to improve educational systems is discussed. Five main categories of research efforts are identified: 1. OER creation, 2. Organization, 3. Dissemination, 4. Utilization and 5. Interventions. Within these categories several critical aspects have been discussed in greater detail.

- Economical aspects: long-term funding for OER is required. The aim to promote equality in access, production and use of open content in all countries is formulated, as open access to learning content contributes to social equality.

- Methodological issues: surveys and anthropological research methods are recommended to study success conditions of OER communities.

- Creating OER: the need to promote a culture of collaborative authoring of resources is identified.

- Quality assurance: quality is acknowledged as a subjective matter, thus the discovery of high-quality OER and the high-quality translation of the resources are important.

- Several experts recommend to look for success factors of Open Source initiatives.

- Future scenarios research should focus on dynamic, interconnected and self-organizing aspects of OER practice.

- Policy issues: most attention is given to copyright and licensing. A recommendation to further push the use of the less restrictive license for OER is formulated. Experts have different opinions on non-commercial licenses.

The idea of do-it-yourself (DIY) OER development site with a special focus on 
PREPRINT Klemke, R., Kalz, M., Specht, M., Ternier, S. (2010). Open educational resources: Conversations in cyberspace - Edited by Susan D'Antoni \& Catriona Savage. British Journal of Educational Technology

supporting developing countries in their OER initiatives is to avoid these countries being in a role of only consumers of OER produced in richer countries. Members of African states remind the community that global OER initiatives should enable opportunities for local content production and distribution. A DIY site to support the creation of OER should include development guides, technological solutions, community support and also some best practice examples to serve users who cannot imagine the variety of OER that exists already.

Section 3 describes a second forum discussing the OECD study of OER. The main topics include an overview survey of currently existing and upcoming OER initiatives and their classification. Second the forum investigated incentives for individuals and institutions to produce and share OER, and third policy implications and policy issues on different levels are discussed.

OER initiatives are categorized according to scale (small/large), provider type (institution, community), and the multidisciplinarity of the repositories. As barriers for establishing OER initiatives, the lack of time and difficulty to engage colleagues and content producers are identified. Many OER producers have not been using any licencing scheme for the produced resources.

Six arguments are identified as motivational background for institutional engagement in OER projects:

1. Altruistic motivation for sharing knowledge in the academic tradition.

2. Educational institutions should leverage taxpayers' by free sharing and reuse of resources

3. FOSS argumentation about what you give, you get back improved.

4. Marketing aspects and positive image for attracting students

5. The option of new possibilities in upcoming business models and alternative ways of making revenue

6. Opening and sharing will speed up the development of new resources and stimulate improvement

Individual motivational aspects for participating and contributing to OER projects include altruism, desire to stimulation of innovation, pleasure of peer activities, reputation gain, and others. As main barriers for establishing OER, the lack of time and skills are mentioned, as also a lack of interest in pedagogical innovation, and the absence of an incentive system. The discussion highlights issues of openness, open innovation of teaching and learning, widening scope of contributors and users of OER resources also to industry and alumni.

Most organisation still have to develop a clear OER policy and have to get rid of the fear to lose their competitive advantage. The unclear legal situation is identified as a major barrier to the use of web-based materials and OER. OER policy development should include a wide range of stakeholders. The joint work 
PREPRINT Klemke, R., Kalz, M., Specht, M., Ternier, S. (2010). Open educational resources: Conversations in cyberspace - Edited by Susan D'Antoni \& Catriona Savage. British Journal of Educational Technology

in partnerships and the cooperation across organisations seems to be essential for the broad uptake or OER initiatives. Also, the core role of governments in the overall process is highlighted.

Section 4 deals with an analysis of issues for the OER movement and draws on a survey that was taken from 620 UNESCO-IIEP members. From this gathered data, six important issues are distilled with two being presented as a concern (quality assurance and copyright/licenses). The data is seperated in two sets: developed and developing countries. This reveals differences in priorities: for instance Copyright and standards is ranked 12 for developing countries while it is considered important in developed countries (ranked 5).

The respondents were asked which stakeholders should take a leadership role. The article gives an indication for the main priorities for higher education institutions, international organizations, national governments and academics. These results are however not striking as one can expect that e.g. supporting learning goes to higher education institutions, while supporting standards is rather a relevant task for an international organization.

The section concludes with an overview on how progress can be made for the key issues. The interesting part of this survey is, that it illustrates that according to someones background (develop(ed/ing) country, region, involved or not involved in an OER community) people tend to formulate other priorties for the OER movement.

\section{Conclusion}

The book documents an important milestone for the OER movement. It presents a broad overview of the different approaches, their problems and future directions for the OER movement. It has a broad coverage of different perspectives and different foci. This broadness lacks some more specific advice for action within the different problem categories. Due to the connection of the OER topic to a lot of different topics (global economics, Web 2.0, etc.), the amount of information and the complexity of the recommendations can be overwhelming. A different method and maybe also the use of a different way of documenting and visualizing the problems discussed in the forums could have improved this problem. In general a discussion of the different methods for collecting expert input for future roadmapping would have contributed to the quality and usefulness of the book. The book represents a good starting point for practitioners and researchers who want to get an overview about the current status of OER and its future directions.

Roland Klemke, Marco Kalz, Marcus Specht, Stefaan Ternier Centre for Learning Science and Technologies, Open Universiteit Nederland roland.klemke@ou.nl, marco.kalz@ou.nl, marcus.specht@ou.nl, stefaan.ternier@ou.nl 
PREPRINT Klemke, R., Kalz, M., Specht, M., Ternier, S. (2010). Open educational

resources: Conversations in cyberspace - Edited by Susan D'Antoni \& Catriona Savage.

British Journal of Educational Technology 